\title{
Pemanfaatan Larva Lalat Black Solder Fly (Hermetia illucens) dengan Berbagai Media Berbeda sebagai Pakan Puyuh
}

\author{
Dini Julia Sari Siregar ${ }^{1 *}$, Warisman², Sri Setyaningrum³ ${ }^{3}$, \\ Hanifah Mutia Z. N. Amrul ${ }^{4}$ \\ Universitas Pembangunan Panca Budi, \\ Email: dini210783@gmail.com
}

(Diajukan: 01 Desember 2021, Direvisi: 13 Januari 2022, Diterima: 09 Februari 2022)

\begin{abstract}
ABSTRAK
Tujuan pengabdian masyarakat yaitu memberikan pelatihan tentang pemanfaatan larva lalat black solder fly (Hermetia illucens) dengan berbagai media berbeda sebagai pakan puyuh di Peternakan Puyuh Desa Sukadamai Timur Kecamatan Hinai Kabupaten Langkat. Kegiatan pengabdian masyarakat ini dilakukan dalam beberapa metode pelaksanaan yaitu kegiatan pertama dengan melaksanakan ceramah dengan beberapa penyampaian materi, kemudian kegiatan kedua yaitu diskusi antara peternak dengan tim pengabdian dan kegiatan terakhir yaitu pengaplikasian secara langsung/ praktek langsung membuat pakan puyuh dengan pemanfaatan larva lalat black solder fly (Hermetia illucens) dengan berbagai media berbeda yang diberikan secara langsung ke ternak puyuh. Pada pengabdian masyarakat ini diperoleh hasil yaitu telah terlaksananya kegiatan yang dimulai dari ceramah, diskusi dan praktek langsung membuat pakan ternak puyuh dengan pemanfaatan larva lalat black solder fly (Hermetia illucens) dengan berbagai media berbeda yang dapat menggantikan pakan komersil sehingga dapat mengurangi biaya pakan. Maka dapat disimpulkan bahwa pemanfaatan larva BSF sebagai pakan puyuh sangat bermanfaat bagi peternak karena dapat menggantikan pemakaian pakan komersil sehingga mengurangi biaya pakan puyuh di Peternakan Puyuh Desa Sukadamai Timur Kecamatan Hinai Kabupaten Langkat.
\end{abstract}

Kata kunci: larva lalat BSF, puyuh, pendapatan masyarakat

\begin{abstract}
The aims of community service were to provide training on the utilization of black solder fly (Hermetia illucens) larvae with various different media as quail feed in Quail Farmer's Sukadamai Timur Village, Hinai District, Langkat Regency. This community service activity was carried out in several methods, the first was lectures, the second was discussions between farmers and the community service team and the last activity was the direct application or direct practice of making quail feed by utilizing black solder fly (Hermetia illucens) larvae with a various different media to giving directly at the quail. This community service resulted in the implementation of the community service program were starting from lectures, discussions and direct practice of manufactured quail feed by utilization of black solder fly (Hermetia illucens) larvae with a various different media that can provide substitute of commercial feed which can reducing of feed cost. So, it can conclude that the utilization of BSF as quail feed very beneficial for farmers because it can replace the use of commercial feed so it can reduce the quail feed cost in Quail Farmer's Sukadamai Timur Village, Hinai District, Langkat Regency.
\end{abstract}

Keywords: BSF larvae, quail, community income 


\section{PENDAHULUAN}

Data BPS (2019), menyatakan bahwa Kecamatan Hinai Kabupaten Langkat secara geografis terletak pada $03^{0} 47^{\prime} 06^{\prime \prime}-03^{0} 53^{\prime} 42^{\prime \prime}$ lintang utara dan $98^{0} 22{ }^{\prime} 28^{\prime \prime}-98^{0} 28^{\prime} 31^{\prime \prime}$ bujur timur, dengan ketinggian 4 mdpl. Jumlah penduduk di Kecamatan Hinai berjumlah 51.088 orang dengan jumlah penduduk laki-laki 25.719 orang dan jumlah penduduk perempuan 25.369 orang. Kecamatan Hinai memiliki luas wilayah 10,526 Ha atau 105,26 $\mathrm{Km}^{2}$. Batas wilayah Kecamatan Hinai di sebelah utara adalah Kecamatan Tanjung Pura, sebelah selatan adalah Kecamatan Wampu, sebelah barat adalah Kecamatan Padang Tualang dan sebelah timur adalah Kecamatan Secanggang.

Kecamatan Hinai memiliki sektor industri, perkebunan, pertanian dan peternakan sebagai sumber mata pencaharian warganya. Kecamatan Hinai terbagi menjadi 13 desa, salah satunya adalah Desa Sukadamai Timur. Sama halnya dengan desa-desa yang ada di Kecamatan Hinai, Desa Sukadamai Timur memiliki potensi wilayah berupa industri, perkebunan, pertanian dan peternakan. Saat ini usaha peternakan yang sedang dikembangkan oleh masyarakat Desa Sukadamai Timur adalah peternakan puyuh. Berdasarkan data BPS (2019), populasi komoditi peternakan di Kecamatan Hinai antara lain sapi potong sebesar 6.658 ekor, kerbau 552 ekor, sapi perah 6 ekor, kambing 17.191 ekor, domba sebesar 56.409 ekor, ayam ras pedaging sebesar 65.411 ekor, ayam kampung 53.450 ekor dan itik lokal 18.495 ekor. Walaupun peternakan puyuh ini belum masuk dalam data Kecamatan Hinai, namun, peternakan puyuh ternyata memiliki peluang yang sangat baik untuk dikembangkan oleh masyarakat Desa Sukadamai timur. Apabila dibandingkan dengan jumlah populasi ayam ras, ayam kampung dan itik, populasi puyuh masih rendah jumlahnya, sehingga kebutuhan akan telur puyuh di Desa ini masih belum mampu tercukupi. Berdasarkan hal ini maka ternak puyuh memiliki prospek yang menguntungkan untuk dikembangkan. Selain itu usaha pengembangan puyuh juga tidak memerlukan modal yang besar maupun lahan yang luas. Masyarakat di Desa Sukadamai Timur selama ini memelihara puyuh sebagai usaha sampingan sehingga pemeliharaannya masih bersifat tradisional.

Pola pemeliharaan secara tradisional inilah, yang mengakibatkan pemenuhan kebutuhan ransum puyuh tidak diperhatikan oleh masyarakat di Desa Sukadamai Timur. Padahal ransum merupakan penentu dalam keberhasilan usaha peternakan. Kebutuhan ransum mencapai $70 \%$ dari total biaya produksi (Louw et al., 2013) dan seiring dengan mahalnya harga ransum komersial, maka diperlukan alternatif penyusunan ransum sendiri 
oleh masyarakat peternak untuk mengurangi biaya ransum puyuh. Harga ransum ternak unggas realitanya pada saat ini meningkat terus menerus dikarenakan salah satu bahan baku sumber protein hewani yaitu tepung ikan harganya semakin tinggi dan ketersediaannya sering berfluaktif serta sangat sering dipalsukan yang mengakibatkan semakin rendah kualitasnya dalam penggunaan nantinya. Harga tepung ikan yang tinggi akan mempengaruhi harga ransum serta biaya produksi. Mengingat penggunaan bahan baku sumber protein yang sangat penting dalam pakan ternak unggas, maka perlu dicari alternatif pengganti tepung ikan dengan memanfaatkan bahan ransum non konvensional yang murah, kualitasnya baik, dan mudah ditemukan di sekitar wilayah peternakan seperti larva BSF (black soldier fly). Larva BSF adalah salah satu bahan pakan alternatif yang memiliki kandungan protein yang cukup tinggi, yaitu berkisar 40-50\%, energi metabolisme $5.282 \mathrm{kkal} / \mathrm{kg}$, lemak kasar 26\%, kalsium 7,56\%, dan fosfor 0,9\% (Makkar et al., 2014; Bosch et al., 2014). Menurut penelitian dari Rambet et al. (2016) bahwa pemanfaatan tepung BSF sebagai substitusi tepung ikan terhadap nilai kecernaan bahan kering, kecernaan energi dan kecernaan protein tidak memiliki efek negatif pada ayam pedaging. Widjastuti et al. (2014) melaporkan bahwa tepung BSF dapat menggantikan penggunaan tepung ikan sebanyak 50-70\% dan menghasilkan pengaruh positif terhadap bobot telur dan produksi telur puyuh.

Berdasarkan hasil penelitian yang sudah dilakukan tersebut dan berpengaruh positif, maka perlu dilakukan pengabdian masyarakat untuk memberikan informasi dan menambah pengetahuan tentang penggunaan tepung larva BSF dan manfaatnya dalam ransum puyuh. Tepung BSF menjadi solusi yang tepat bagi peternak dari segi ekonomi, mengingat mahalnya harga pakan komersil. Pemanfaatan tepung larva BSF dilakukan dengan cara mengembangbiakkan larva BSF dalam media yang ada disekitar peternak seperti limbah buah-buahan dan sayuran serta kotoran puyuh kemudian diolah menjadi tepung BSF. Harga tepung ikan lebih mahal bila dibandingkan harga proses pengolahan BSF menjadi tepung BSF dan menghasilkan pengaruh yang positif pada puyuh. Hal tersebut sesuai dengan penelitian Zulpani (2021) yang melaporkan bahwa pemanfaatan tepung larva BSF yang dikembangbiakan dalam media kotoran puyuh, limbah buah-buahan dan sayuran, serta tandan buah kosong kelapa sawit memberikan hasil yang positif terhadap pertumbuhan dan produksi telur puyuh. Oleh sebab itu diharapkan dapat menekan biaya produksi dan mudah diaplikasikan oleh peternak. Pengabdian pada masyarakat ini bertujuan untuk memberikan pelatihan tentang pemanfaatan larva lalat black solder fly (Hermetia illucens) dengan berbagai media berbeda sebagai pakan puyuh di peternakan puyuh Desa Sukadamai Timur Kecamatan Hinai Kabupaten Langkat. 


\section{METODE}

Pelaksanaan kegiatan pengabdian masyarakat telah berlangsung pada bulan Mei sampai dengan Juni 2021 yang bekerja sama dengan mitra para peternak puyuh di Desa Sukadamai Timur, Kecamatan Hinai, Kabupaten Langkat. Bahan-bahan yang digunakan dalam pengabdian masyarakat ini adalah lalat BSF (Hermetia illucens) dengan fase larva, media tumbuh berupa limbah sayur dan buah-buahan serta kotoran puyuh. Adapun alat-alat yang telah digunakan yaitu ember dan kandang untuk pemeliharaan larva BSF.

Metode yang telah dilaksanakan dalam kegiatan pengabdian masyarakat ini ada 3 tahap yaitu tahapan pertama berupa ceramah yang dilanjutkan tahap kedua dengan diskusi dan tahap ketiga melaksakan praktek langsung. Metode pelaksanaan yang berlangsung dalam pengabdian masyarakat yaitu 30\% berupa teori dan $70 \%$ berupa praktek langsung. Ceramah dilakukan pada para peternak puyuh yang dilanjutkan dengan diskusi (tanya jawab) dan praktek langsung di lapangan. Pada pelaksanaan kegiatan ceramah ini materi diberikan kepada peternak puyuh. Materi ceramah terbagi menjadi dua yaitu yang pertama tentang potensi larva BSF sebagai pakan puyuh dan yang kedua tentang pemanfaatan limbah yang ada di sekitar lingkungan peternak sebagai media perkembangbiakan larva lalat BSF. Kegiatan praktek langsung meliputi pengembangbiakan larva BSF dan penggunaannya dalam campuran ransum puyuh. Setelah praktek langsung selanjutnya dilakukan evaluasi untuk mengetahui tingkat keberhasilan program dengan cara penilaian melalui wawancara dan pemantauan.

\section{HASIL, PEMBAHASAN, DAN DAMPAK}

Jalannya pelaksanaan kegiatan pengabdian masyarakat yang sudah dilakukan antara lain dengan persiapan program pengabdian masyarakat, pelaksanaan kegiatan program pengabdian masyarakat dan evaluasi dan monitoring pelaksanaan kegiatan program pengabdian masyarakat di peternakan puyuh tersebut.

\section{Persiapan Kegiatan Program Pengabdian Masyarakat}

Pada persiapan kegiatan pengabdian masyarakat ini dilakukan dengan cara melakukan koordinasi antar tim pengabdian masyarakat yaitu dosen, mahasiswa dan alumni dimana nantinya dapat menentukan kegiatan-kegiatan yang akan dilaksanakan serta pembagian tugas masing-masing tim dalam berjalannya kegiatan pelaksanaan program pengabdian masyarakat. Kegiatan yang dibagi pada masing-masing tim pengabdian adalah survei lokasi pengabdian, survei bahan baku, pembelian alat-alat pengabdian dan persiapan pelaksanaan kegiatan 
pengabdian masyarakat. Berdasarkan hasil survei lokasi pengabdian di peternakan puyuh Desa Sukadamai Timur, Kecamatan Hinai, Kabupaten Langkat didapatkan data jumlah populasi puyuh, kondisi kandang puyuh, kendala yang dihadapi peternak dan obat-obatan yang digunakan peternak. Hasil survei bahan baku di tempat pengabdian masyarakat didapatkan hasil bahwa bahan baku berupa media perkembangbiakan larva lalat BSF yang meliputi limbah sayuran dan buah-buahan dan kotoran puyuh disediakan oleh peternak, sedangkan telur larva BSF disediakan oleh tim pengabdian masyarakat. Kegiatan persiapan pelaksanaan program pengabdian masyarakat dilakukan dengan menyiapkan semua keperluan bahan baku dan peralatan untuk pembuatan media perkembangbiakan larva lalat BSF (Hermetia illucens) sebagai pakan puyuh untuk meningkatkan pendapatan masyarakat. Proses pengembangbiakan larva BSF ditampilkan pada Gambar 1.

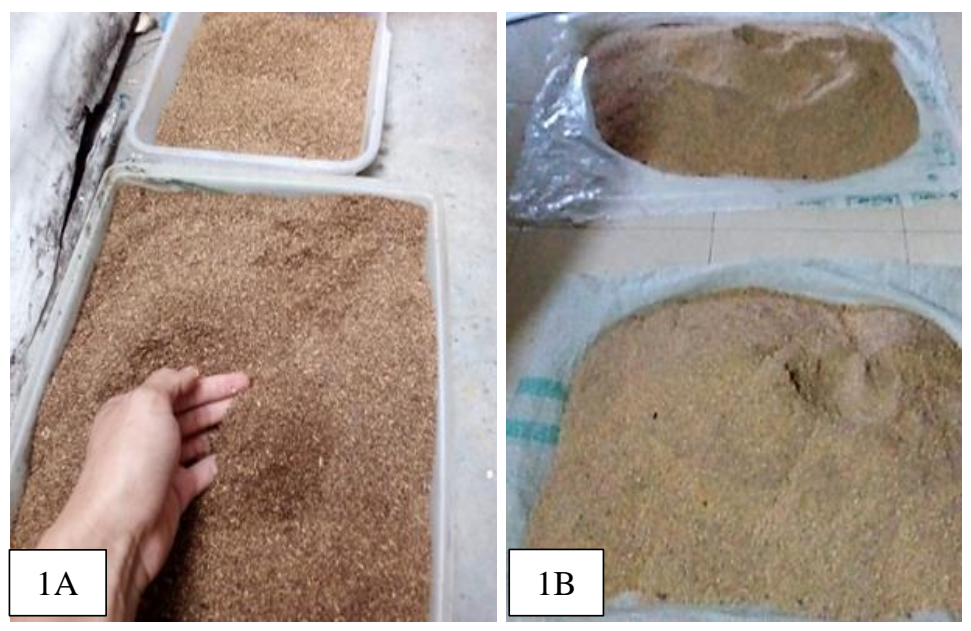

Gambar 1. Proses Pengembangbiakan Larva BSF. 1A. Tepung larva BSF. 1B. Pencampuran tepung larva BSF dengan pakan puyuh

\section{Pelaksanaan Kegiatan Pengabdian Masyarakat}

Pengabdian masyarakat dilakukan dengan cara ceramah dan diskusi serta praktek langsung. Hasil kegiatan ceramah dan diskusi meliputi dua materi yaitu materi tentang potensi larva BSF sebagai pakan puyuh dan materi tentang pemanfaatan limbah yang ada di sekitar lingkungan peternak sebagai media perkembangbiakan larva lalat BSF.

Ceramah dengan materi pertama tentang potensi larva BSF sebagai pakan puyuh. Dalam ceramah ini masayarakat dijelaskan tentang kandungan zat gizi larva BSF yang meliputi kandungan protein kasar, energi, lemak kasar dan serat kasar yang masing-masing terdiri dari protein kasar 44,26\% dan lemak kasar 29,65\% (Fahmi et al., 2007). Lebih lanjut dijelaskan bahwa, larva BSF juga mengandung asam lemak, mineral dan asam amino. Asam amino yang terkandung dalam BSF hampir sama dengan kandungan asam amino pada tepung ikan dan hampir mirip dengan profil asam amino yang terdapat pada bungkil kedela 
(Elwert et al., 2010); Veldkamp dan Bosch, 2015). Dengan adanya pemaparan materi ini masyarakat begitu antusias dan tertarik untuk mengembangkan larva BSF sebagai pakan puyuh.

Penyampaian materi yang kedua yaitu tentang pemanfaatan limbah yang ada di sekitar lingkungan peternak sebagai sebagai media hidup perkembangbiakan larva lalat BSF. Materi yang disampaikan yaitu perkembangbiakan larva BSF dengan memanfaatkan limbah yang ada disekitar peternak seperti limbah sayuran dan buah-buahan dan kotoran puyuh sebagai media hidup larva BSF. Penggunaan limbah-limbah tersebut ternyata mampu menghasilkan larva BSF yang dapat digunakan sebagai pakan puyuh dan berdampak positif terhadap pertumbuhan dan produksi telur puyuh (Zulpani, 2021). Kegiatan pengabdian masyarakat ini semakin meningkatkan minat bagi para peternak puyuh untuk menggunakan larva BSF sebagai campuran dalam pakan puyuh.

Kegiatan praktek langsung pengembangbiakan larva BSF dilakukan dengan menggunakan berbagai macam media menggunakan bahan-bahan yang terdiri dari limbah sayuran dan buah-buahan dan kotoran puyuh. Cara pengembangbiakan larva BSF dalam limbah sayuran dan buah-buahan dan kotoran puyuh dilakukan dengan cara memasukkan baby larva BSF dalam masing-masing media tersebut, kemudian dipanen pada umur 20 hari. Selanjutnya larva BSF dikeringkan dan diblender hingga menjadi tepung dan digunakan sebagai campuran dalam pakan puyuh. Pemberian tepung larva BSF dalam campuran pakan puyuh dilakukan setiap hari dan diberikan secara adlibitum. Penggunaan tepung larva BSF ini dalam campuran pakan puyuh ini digunakan untuk menggantikan bahan baku sumber protein berupa tepung ikan yang mahal harganya. Penimbangan bobot badan puyuh dilakukan setiap minggu untuk mengetahui pertumbuhan puyuh setelah mendapat pakan tepung larva BSF dalam campuran pakan puyuh.

\section{Kegiatan Evaluasi Pelaksanaan Program Pengabdian Masyarakat}

Kegiatan evaluasi yang dilakukan dalam pengabdian masyarakat ini meliputi evaluasi pertumbuhan larva BSF dalam berbagai media, evaluasi pemberian tepung larva BSF sebagai pakan puyuh dan evaluasi pertumbuhan puyuh setelah mendapatkan pakan tepung BSF. Kegiatan evaluasi selain dilakukan untuk pelaksanaan program juga dilakukan untuk keberlanjutan program. Kegiatan evaluasi tersebut dilakukan setiap minggu, hal ini dilakukan dengan tujuan untuk mencegah atau mengurangi terjadinya masalah selama pelaksanaan pengabdian masyarakat dan apabila terjadi masalah dapat segera ditangani untuk melakukan pendampingan serta monitoring terhadap peternak. Evaluasi dilakukan 
dalam 2 tahap. Evaluasi tahap I dilakukan untuk melihat apakah hasil pelatihan sudah diterapkan oleh peternak puyuh dan evaluasi tahap II dilakukan dalam bentuk pemantauan penerapan pemanfaatan BSF sebagai pakan puyuh untuk menggantikan pakan komersil yang biasa digunakan oleh peternak.

Dampak pengabdian masyarakat ini kepada mitra yaitu peternak puyuh selama ini belum mengetahui tentang penggunaan tepung BSF sebagai bahan pakan yang dapat menggantikan tepung ikan. Namun setelah pelaksanaan pengabdian masyarakat, peternak sudah mulai memahami tentang manfaat tepung BSF sebagai bahan pakan yang dapat digunakan sebagai campuran dalam ransum puyuh.

\section{SIMPULAN}

Hasil pelaksanaan pengabdian masyarakat ini dapat disimpulkan bahwa pemanfaatan larva BSF sebagai pakan puyuh sangat bermanfaat bagi peternak karena dapat menggantikan pemakaian pakan komersil sehingga mengurangi biaya pakan puyuh di Desa Sukadamai Timur Kecamatan Hinai Kabupaten Langkat.

\section{DAFTAR PUSTAKA}

Badan Pusat Statistik Kabupaten Langkat. 2019. Kecamatan Hinai dalam Angka 2019. BPS Kabupaten Langkat, Langkat.

Bosch, G., Sheng, Z., Dennis G.A.B.O., dan Wouter, H.H. 2014. Protein quality of insects as potential ingredients for dog and cat foods. J Nutr. Sci., 3, 1-4.

Elwert C, Knips I., dan Katz, P. 2010. A novel protein source: Maggot meal of the Black Soldier Fly (Hermetia illucens) in broiler feed. In: Tagung Schweine-und Gefugelernahrung (Lutherstadt Witterberg, 23-25 Novemb 2010). Halle (Germany): Institut fur Agrarund Ernahrungweissenschafte. Universitat HalleWittenberg. p. 140142.

Fahmi, M. R, Saurin, H., I Wayan, S. 2007. Potensi maggot sebagai salah satu sumber protein pakan ikan.Dalam: Dukungan Teknologi untuk Meningkatkan Produk Pangan Hewan dalam Rangka Pemenuhan Gizi Masyarakat. Prosiding Seminar Nasional Hasil Pangan Sedunia XXVII. Bogor (Indonesia). Puslitbangnak. 125-130.

Louw, A., Jacques, S., dan Mariëtte, G. 2013. Pork and broiler industry supply chain study with emphasis on feed and feedrelated issues. J Agric Econ Develop, 2 (4), 134-146.

Makkar, H.P.S., Tran, G., Heuze, V., dan Ankreas, P. 2014. State Of The Art On Use Of Insects As Animal Feed. Anim Feed Sci Technol, 197, 1-33.

Rambet, V., Umboh, J.F, Tulung, Y.L.R. dan Kowel, Y.H.S. 2016. Kecernaan protein dan energi ransum broiler yang menggunakan tepung maggot (Hermetia illucens) sebagai pengganti tepung ikan. J Zootek. 36:13-22. 
Widjastuti, T., Wiradimadja, R, dan Rusmana, D. 2014. The effect of substitution of fish meal by Black Soldier Fly (Hermetia illucens) maggot meal in the diet on production performance of quail (Coturnix coturnix japonica). Anim Sci., 57, 125-129.

Veldkamp, T.G., Van Duinkerken, G., Van Huis, A., Lakemond, C.M.M., Ottevanger, E., Bosch, G, Van Boekel, M.A.J.S. 2012. Insects as a suistanable feed ingredient in pig and poultry diets-a feasibility study. Wageningen (Netherlands): Wageningen UR Livestock Research.

Zulpani, Z. 2021. Pemanfaatan Maggot (Hermetia illucens) dari Berbagai Media Tumbuh sebagai Pengganti Tepung Ikan pada Pakan terhadap Produksi Puyuh. Program Studi Peternaakan, Universitas Pembangunan Panca Budi, Medan. (Skripsi). 